\title{
Analysis of immunoexpression of common cancer stem cell markers in ameloblastoma
}

\author{
GULSAN ARA SATHI $^{1}$, RYO TAMAMURA ${ }^{1}$, HIDETSUGU TSUJIGIWA ${ }^{1}$, NAOKI KATASE ${ }^{1}$, \\ MATHIEU LEFEUVRE ${ }^{1}$, CHONG HUAT SIAR ${ }^{2}$, HIROYUKI MATSUDA ${ }^{1}$ and HITOSHI NAGATSUKA ${ }^{1}$ \\ ${ }^{1}$ Department of Oral Pathology and Medicine, Graduate School of Medicine, Dentistry and Pharmaceutical Sciences, \\ Okayama University, Okayama, Japan; ${ }^{2}$ Department of Oral Pathology, Oral Medicine and Periodontology, \\ Faculty of Dentistry, University of Malaya, Kuala Lumpur, Malaysia
}

Received October 5, 2011; Accepted December 2, 2011

DOI: $10.3892 / \mathrm{etm} .2011 .437$

\begin{abstract}
Recent studies have established that, in benign tumors, a large number of cancer stem cells are present, which have great implications in tumor development. However, in ameloblastoma, a highly aggressive, locally invasive tumor with a high recurrence rate, whether or not cancer stem-like cells are present remains undetermined. Therefore, in this study we analyzed the protein expression of three candidate stem cell markers in ameloblastoma. Immunohistochemical staining for cancer stem cell (CSC) markers (CD133, CD44 and ABCG2) and for the proliferation marker Ki-67 was performed using 23 ameloblastoma cases. In all 23 samples, CD133, CD44 and ABCG2 were expressed. Nine (39.13\%) cases showed high expression and 14 cases $(60.87 \%)$ showed low expression for CD133. Twelve of the 23 cases (52.17\%) showed high expression and 11 cases (47.83\%) showed low expression for both CD44 and ABCG2, respectively. Ki-67 was mainly expressed in peripheral ameloblast-like cells, suggesting that these cells have a higher degree of differentiation and, therefore, are less likely to contain cancer stem-like cells. On the other hand, cells positive for CSC markers situated at the close proximity to peripheral cells were devoid of Ki-67 and may have the potential to be cancer stem-like cells. After analyzing the correlation between expression of three CSC markers with clinicopathological factors and Ki-67 expression, only CD44 expression was correlated with tumor recurrence $(\mathrm{P}=0.0391)$. In conclusion, this study showed various expression patterns of different types of cancer stem cell markers and the presence of candidate CSC-like cells in ameloblastoma, which are possibly involved in cell proliferation, tumor progression and recurrence.
\end{abstract}

Correspondence to: Dr Hitoshi Nagatsuka, Department of Oral Pathology and Medicine, Graduate School of Medicine, Dentistry and Pharmaceutical Sciences, Okayama University, 2-5-1 Shikata-cho, Okayama 700-8525, Japan

E-mail: jin@md.okayama-u.ac.jp

Key words: ameloblastoma, cancer stem cell, CD133, CD44, ABCG2, immunohistochemistry

\section{Introduction}

Ameloblastoma is the most frequently encountered benign, locally invasive tumor and the second most common odontogenic tumor (1). It may arise from rests of dental lamina, from a developing enamel organ or from basal cells of the oral mucosa. Ameloblastomas tend to infiltrate between intact cancellous bones at the periphery of the lesion before bone resorption becomes radiographically evident. As a result, the actual margin of the tumor often extends beyond its apparent radiographic or clinical margin. Attempts to remove the tumor often leave small islands of tumor, which later result in recurrence in $50-90 \%$ of cases (2). This has raised questions regarding the tumor cell populations that are responsible for tumor growth and recurrence.

In the past few years, it has been hypothesized that tumors are most likely initiated in normal stem cells or their immediate descendants, and then are perpetuated by a minority of these cells, known as cancer stem cells (CSCs) or tumor-initiating cells (TICs) (3). According to the American Association for Cancer Research (AACR), 'a cell within a tumor that possesses the capacity to self-renew and to cause heterogeneous lineages of cancer cells that comprise the tumor is known as a cancer stem cell'. This observation implies that within a given tumor, there exists a small population of cells with the capacity to behave like stem cells (4). The difficulty in eradicating tumors may be due to the fact that conventional treatments target the bulk of the tumor cells leaving unaffected the CSCs, which like their normal counterparts, maintain tumor tissue. According to this hypothesis, identifying and exterminating CSCs may be an effective treatment modality (5).

Recently, several CD markers have been identified as solid CSC markers. CD133, also known as PROML1 or prominin, is a stem cell surface antigen that has been recently identified as a potential CSC marker in brain, colon, hepatocellular and prostate cancer (6-10). CD44, also known as homing cell adhesion molecule, is a cell surface glycoprotein expressed on lymphocytes, monocytes and granulocytes, which has been identified as a stem cell marker for breast, prostate, pancreatic and head and neck cancer (6,11-13). The ABCG2 transporter is a member of the ATP binding cassette transporter family (14) responsible for the side population phenotype in various 
Table I. Clinical and histopathological data of the patients with ameloblastoma.

\begin{tabular}{rllll}
\hline Case no. & Gender & Age (years) & Location & \multicolumn{1}{c}{ Histological type } \\
\hline 1 & Female & 41 & Mandible & Solid multilocular (Plexiform) \\
2 & Male & 60 & Mandible & Solid multilocular (Mixed) \\
3 & Male & 58 & Mandible & Solid multilocular (Mixed) \\
4 & Male & 31 & Mandible & Solid multilocular (Plexiform) \\
5 & Male & 69 & Mandible & Solid multilocular (Mixed) \\
6 & Male & 71 & Mandible & Solid multilocular (Mixed) \\
7 & Male & 39 & Maxilla & Solid multilocular (Mixed) \\
8 & Male & 25 & Maxiila & Solid multilocular (Plexiform) \\
9 & Male & 25 & Maxilla & Solid multilocular (Mixed) \\
10 & Male & 21 & Maxilla & Solid multilocular (Mixed) \\
11 & Female & 46 & Mandible & Solid multilocular (Mixed) \\
12 & Female & 42 & Mandible & Solid multilocular (Mixed) \\
13 & Female & 30 & Maxilla & Solid multilocular (Plexiform) \\
14 & Female & 27 & Maxilla & Solid multilocular (Plexiform) \\
15 & Male & 45 & Mandible & Solid multilocular (Follicular) \\
16 & Male & Maxilla & Solid multilocular (Mixed) \\
17 & Male & Mandible & Solid multilocular (Follicular) \\
18 & Male & Mandible & Solid multilocular (Mixed) \\
19 & Male & 53 & Sandible & Solid multilocular (Mixed) \\
20 & Male & 55 & Mandible & Solid multilocular (Mixed) \\
21 & Female & 55 & Saxilla & Solid multilocular (Plexiform) \\
22 & Female & 83 & Maxilla & Solid multilocular (Mixed) \\
23 & Female & 81 & Solid multilocular (Follicular) \\
\hline
\end{tabular}

aecurrent case.

human cancers and the corresponding non-malignant tissues, and is widely used to detect and isolate somatic stem/ progenitor cells (7). Xu et al for the first time demonstrated that stem-like cells are present in benign tumors. They isolated self-renewable and multipotent stem-like cells from various pituitary adenomas. Implanted into immune compromised mice, these cells initiated transplantable pituitary tumors that resembled the primary tumors (15).

Ameloblastoma is a benign tumor with two histologically distinct cell types: peripheral ameloblast-like cells and central stellate reticulum-like cells. The presence of cancer stem-like cells in ameloblastoma remains undetermined. However, if cancer stem-like cells are present in ameloblastoma, it is important to identify which type of cell possesses these cancer stem-like characteristics and is responsible for ameloblastoma progression and recurrence. Therefore, in this study we analyzed the protein expression of the three most putative candidate stem cell markers, CD133, CD44 and ABCG2, in ameloblastoma.

\section{Materials and methods}

Tissue sample selection. Twenty-three blocks from 17 cases embedded in paraffin were selected from the Surgical Pathology Unit of the Department of Oral Pathology and Medicine, Graduate School of Medicine, Dentistry and
Pharmaceutical Science of Okayama University, Japan. These samples were fixed in $10 \%$ neutral buffered formalin and routinely processed and embedded in paraffin. Histological diagnosis was carried out by routine $\mathrm{H} \& \mathrm{E}$, according to WHO histological typing of odontogenic tumors. Clinical characteristics and histological types of the cases are shown in Table I.

Immunohistochemistry. Sections $(3-\mu \mathrm{m})$ mounted on salinized slides were used for immunohistochemical staining. Briefly, sections were deparaffinized in a series of xylene for $15 \mathrm{~min}$ and rehydrated in graded ethanol solutions. Endogenous peroxidase activity was blocked by incubating the sections in $0.3 \% \mathrm{H}_{2} \mathrm{O}_{2}$ in methanol for $30 \mathrm{~min}$. Antigen retrieval was achieved by heat treatment using $10 \mathrm{mM}$ citrate buffer solution pH 6.0 (CD133, CD44, ABCG2 and Ki-67). After treatment with normal serum, the sections with primary antibodies were incubated at $4{ }^{\circ} \mathrm{C}$ overnight. The tagging of the primary antibody was achieved by subsequent application of anti-goat/mouse IgG and avidin-biotin complexes (Mouse ABC kit; Vector Laboratories, Inc., Burlingame, CA, USA) or Envision peroxidase detecting reagent (Dako, Carpinteria, CA, USA). Visualization of the immunohistochemical reaction was performed by developing the enzyme complex with $\mathrm{DAB} / \mathrm{H}_{2} \mathrm{O}_{2}$ solution (Histofine DAB substrate; Nichirei, Japan) and counterstaining with Mayer's hematoxylin. The antibodies used are listed in Table II. 
Table II. Details of the antibodies used.

\begin{tabular}{lcccc}
\hline Antibody & Clonality & Supplier & Dilution & Treatment \\
\hline CD133 & Rabbit polyclonal & Abcam, Cambridge, MA, USA & $1: 300$ & Heat \\
CD44 & Rabbit polyclonal & Abcam, Cambridge, MA, USA & $1: 200$ & Heat \\
ABCG2 & Mouse monoclonal & Abcam, Cambridge, MA, USA & $1: 50$ & Heat \\
Ki-67 & Mouse monoclonal & Dako, Denmark & $1: 50$ & Heat \\
\hline
\end{tabular}

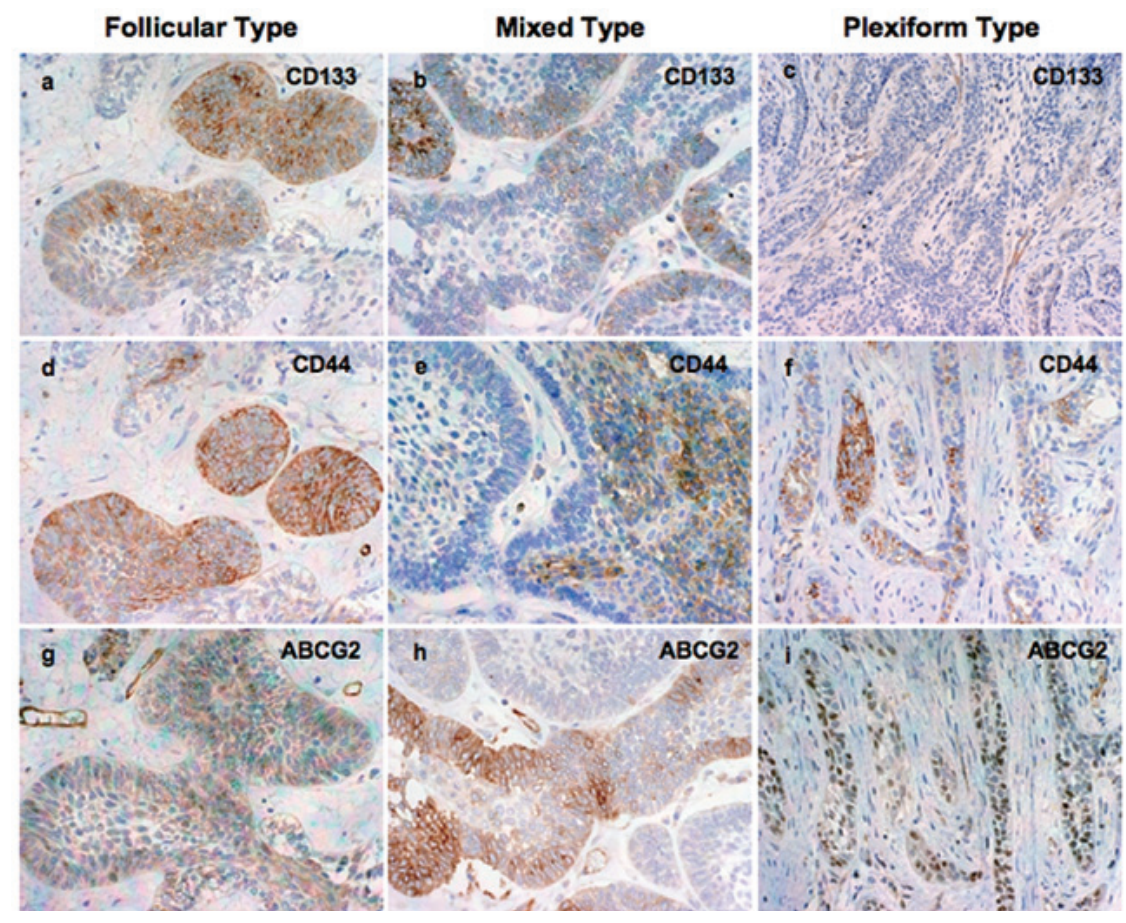

Figure 1. Immunostaining for (a-c) CD133, (d-f) CD44 and (g-i) ABCG2 in different types of ameloblastoma.

Ki-67-positive cell count. For analysis of the percentage of $\mathrm{Ki}-67$-positive cells, in each tissue section, several fields were chosen randomly and the fields that complied with the requirements were further selected. The requirements were that the well-preserved fields were stained by anti-Ki-67 antibodies. Clear brown nuclei were regarded as positive cells, and at least three to five fields in each section were counted using an eyepiece micrometer and counted at x40 magnification. The process was repeated three times to decrease the operator error. The percent labeling index (LI) (Number of positive cells/total cells x 100) was calculated for each field.

Scoring for protein expression. Immunoreactivity with each of the antibodies was graded in each histopathological compartment of ameloblastoma: low expression (0-30\%) and high expression $(\geq 31 \%)$.

Statistical analysis. The LI of Ki-67 was counted; the mean and the standard deviation (SD) were calculated. The Student's t-test was used, and P-values $<0.05$ were considered to denote statistical significance. Clinicopathological data and low and high expression of different CSC markers were statistically compared using the t-test and Fisher's exact test, and P-values $<0.05$ were considered to denote statistical significance.
All computations were computer-based using Stat View for Windows version 5.0 statistical program, SAS Inc.

\section{Results}

Immunohistochemistry. Representative immunohistochemical staining for the three CSC proteins investigated in this study are shown in Fig. 1.

CD133. The location of staining was cytoplasmic. Intense immunostaining was observed in small tumor follicles and peripheral ameloblast-like cells. In plexiform type, several cases showed a positive immunoreaction with peripheral columnar cells, with few central cells at the close vicinity of the peripheral ameloblast. Certain cases showed a weak or negative reaction. Nine $(39.13 \%)$ cases showed high and 14 cases $(60.87 \%)$ showed low CD133 expression (Fig. 1a-c).

$C D 44$. The location of staining was cytoplasmic. In several cases, CD44 expression was strong in small tumor follicles. However, plexiform type ameloblastoma showed intense immunoreaction in center stellate reticulum-like cells. Twelve of 23 cases $(52.17 \%)$ showed high and 11 cases $(47.83 \%)$ showed low CD44 expression (Fig. 1d-f). 
$A B C G 2$. The location of staining of these molecules was also cytoplasmic. Diffuse and intense staining was observed in peripheral ameloblast-like cells, the budding area and central stellate reticulum-like cells of the tumors. Small tumor follicles showed weak immunoexpression. High ABCG2 expression was observed in $12(52.17 \%)$ out of 23 cases and 11 cases (47.83\%) showed low expression (Fig. 1g-i).

Ki-67 expression and LI. Ki-67 antigen was expressed in $82.6 \%$ of ameloblastoma cases and the positive cells present in the different histological types were counted. Ki-67 expression was mainly observed in the nuclei of the peripheral ameloblastlike cells, and only a few positive cells were observed in the central stellate reticulum-like cells (Fig. 2). Most of the tissue sections did not contain positive central cells, and peripheral cells are known to reflect the growth activity of ameloblastoma (16). The mean and standard deviation of Ki-67 LI was 23.13 and 13.9 , respectively.

Correlation between CSC expression and clinicopathological factors. As shown in Table III, only CD44 expression was correlated with tumor recurrence (0.0391) and ABCG2 was correlated with the tumor location (0.0361). However, there was no significant association between CD133 expression and clinicopathological features.

Correlation between CSC expression and Ki-67-positive cells. Next, we analyzed the possible correlation between the high and low expression of three CSC markers and Ki-67 expression in all ameloblastoma cases using the Student's t-test. No significant association was observed between Ki-67 expression and expression of all three CSC markers (Table III).

\section{Discussion}

Tumor recurrence after curative surgery remains a major obstacle for improving overall cancer survival. Recurrence may be in part due to the existence of CSCs. Growing evidence suggests that human cancers are stem cell diseases, and only a small subpopulation of cancer cells, endowed with stem cell-like features, may be responsible for tumor initiation and progression (17). Novel strategies for successful tumor treatment should focus on the elimination of CSCs. In this study, we analyzed immunohistochemical staining to detect the expression of three different CSC markers in relation to the proliferation activity of the tumor cells in ameloblastoma, a highly apoptosis-resistant and invasive tumor with a high recurrence rate and possesing different histological patterns (18-21).

Increasing evidence highlights the role of CD133 as a marker of CSCs in various human tumors as well as in ameloblastoma $(22,23)$. CD44 is one of the cell surface markers currently used to identify CSCs in various solid tumors $(6,11,12)$. CD133 was found to be expressed in combination with $\mathrm{CD} 44^{+}$in prostate tumors. These cells were found to be capable of self-renewal, proliferation and multi-lineage differentiation in vitro to recapitulate the original tumor phenotype, consistent with CSC properties (6). In the present study, CD133, the most important CSC marker, was stained fairly well in $39.13 \%$ of the cases. CD44 is another important candidate stem cell marker and demonstrated positive expression in $52.17 \%$ of the cases. The

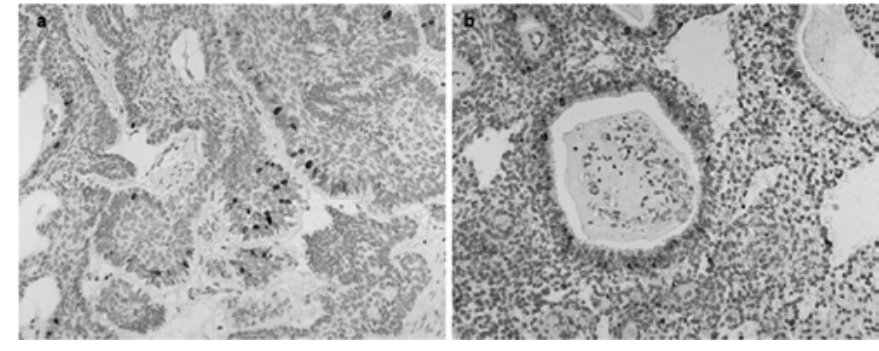

Figure 2. Representative cases of Ki-67 immunoexpression in ameloblastoma. (a and b) Ki-67 expressionmainly observed in the nuclei of the peripheral ameloblast-like cells and (b) only a few positive cells were seen in the central stellate reticulum-like cells.

samples positive for both CD133 and CD44 showed that the two markers present a similar expression pattern and are mainly located in peripheral cells. This co-expression suggests that these two molecules may be potential biomarkers for the initiation, progression and cell differentiation in ameloblastoma (24).

It has already been reported that $\mathrm{CD} 44^{+}$cells have the capability to initiate tumor recurrence upon completion of treatment (25). In the present study, statistical data revealed that CD44 expression was significantly associated with tumor recurrence. This suggests that, in ameloblastoma, CD44 may play a central role in tumor recurrence. ABCG2 is a member of the ATP binding cassette transporter family, is widely expressed in stem cells, and is recognized as a universal marker of stem cells. Recent studies strongly suggest that ABCG2 expression in tumors may contribute to tumor growth initiation, invasiveness and relapse (26-30). In this study, diffuse expression of ABCG2 was observed in ameloblastoma, suggesting that ABCG2 may enhance the proliferation and invasion of tumors by maintaining the existing cancer stemlike cells in ameloblastoma. This also supports other studies regarding ABCG2 expression in ameloblastoma (22).

In ameloblastoma, even though different types of histological variations are present, two distinct cell types are observed in all subtypes: peripheral columnar epithelium or ameloblast-like cells and central stellate reticulum-like cells (1). Peripheral cells are always situated at the invasive front, but no morphological differentiation can be observed. By contrast, in many cases, central stellate reticulum-like cells show cellular differentiation and morphological change (1). In the present experiment, it was observed that most of the peripheral cells positive for CSC markers were also positive for the proliferative marker Ki-67. However, cell proliferation marker Ki-67-positive cells have a higher degree of differentiation and are, therefore, less likely to contain cancer stem-like cells (31). Therefore, in these cells, it is possible that CSC markers only maintain cellular proliferation and tumor progression. In contrast, few CSC marker-positive central stellate reticulum-like cells situated at the close vicinity of the peripheral cells were devoid of Ki-67 expression. Thus, these cells may have the potential to be cancer stem-like cells. In accordance with this hypothesis, these central stellate reticulum-like cells may change their morphology and differentiate into different types of cellular patterns, for example, granular, squamous and acanthomatous type (1).

The presence of candidate CSCs in ameloblastoma supports the findings of a previous study which revealed that it 
Table III. Correlation between CSC markers expression and clinicopathological factors in ameloblastoma.

\begin{tabular}{|c|c|c|c|c|}
\hline & \multicolumn{4}{|c|}{ CD133 expression } \\
\hline & Total $[\mathrm{n}=23(\%)]$ & High $(n=9 ; 39.13 \%)$ & Low $(n=14 ; 60.87 \%)$ & P-value \\
\hline Age (years; mean $\pm S D)^{a}$ & $47.33 \pm 9.73$ & $43.71 \pm 21.83$ & 0.1874 & \\
\hline Gender $^{\mathrm{b}}$ & & & & 0.0858 \\
\hline Male & $15(65.22)$ & $8(53.33)$ & $7(46.67)$ & \\
\hline Female & $8(34.78)$ & $1 \quad(12.5)$ & $7 \quad(87.5)$ & \\
\hline Location $^{\mathrm{b}}$ & & & & 0.2283 \\
\hline Mandible & $14(60.87)$ & $7(50.0)$ & $7 \quad(50.0)$ & \\
\hline Maxilla & $9(39.13)$ & $2(22.22)$ & $7(77.78)$ & \\
\hline Recurrence $^{b}$ & & & & 0.6802 \\
\hline Yes & $11(47.83)$ & $5(45.45)$ & $6(54.55)$ & \\
\hline No & $12(52.17)$ & $4(33.33)$ & $8(66.67)$ & \\
\hline \multirow[t]{3}{*}{$\mathrm{Ki}-67(\text { mean } \pm \mathrm{SD})^{\mathrm{a}}$} & $27.80 \pm 13.84$ & $19.63 \pm 13.44$ & 0.1892 & \\
\hline & \multicolumn{4}{|c|}{ CD44 expression } \\
\hline & Total $[n=23(\%)]$ & High $(n=12 ; 52.17 \%)$ & Low $(n=11 ; 47.83 \%)$ & P-value \\
\hline Age $(\text { years; mean } \pm S D)^{a}$ & $48.58 \pm 16.31$ & $41.36 \pm 19.48$ & 0.1988 & \\
\hline Gender $^{\mathrm{b}}$ & & & & 0.2203 \\
\hline Male & $12(52.17)$ & $8(66.67)$ & $4(33.33)$ & \\
\hline Female & $11(47.83)$ & $4(36.36)$ & $7(63.64)$ & \\
\hline Location $^{\mathrm{b}}$ & & & & 0.0995 \\
\hline Mandible & $13(56.52)$ & $9(69.23)$ & $4(30.77)$ & \\
\hline Maxilla & $10(43.48)$ & $3(30.0)$ & $7 \quad(70.0)$ & \\
\hline Recurrence $^{\mathrm{b}}$ & & & & $0.0391^{\mathrm{c}}$ \\
\hline Yes & $11(47.83)$ & $3(27.27)$ & $8(72.73)$ & \\
\hline No & $12(52.17)$ & $9 \quad(75.0)$ & $3(25.0)$ & \\
\hline \multirow[t]{3}{*}{$\mathrm{Ki}-67(\text { mean } \pm \mathrm{SD})^{\mathrm{a}}$} & $22.21 \pm 15.35$ & $24.15 \pm 12.86$ & 0.7579 & \\
\hline & \multicolumn{4}{|c|}{ ABCG2 expression } \\
\hline & Total $[\mathrm{n}=23(\%)]$ & High $(n=12 ; 52.17 \%)$ & Low $(\mathrm{n}=11 ; 47.83 \%)$ & P-value \\
\hline Age $(\text { years; mean } \pm S D)^{a}$ & $44.00 \pm 14.23$ & $46.17 \pm 21.26$ & 0.9039 & \\
\hline Gender $^{\mathrm{b}}$ & & & & 0.1930 \\
\hline Male & $16(69.57)$ & $10(62.5)$ & $6 \quad(37.5)$ & \\
\hline Female & $7(30.43)$ & $2(28.57)$ & $5(71.43)$ & \\
\hline Location $^{\mathrm{b}}$ & & & & $0.0361^{\mathrm{c}}$ \\
\hline Mandible & $14(60.87)$ & $10(71.43)$ & $4(28.57)$ & \\
\hline Maxilla & $9(39.13)$ & $2(22.22)$ & $7(77.78)$ & \\
\hline Recurrence $^{\mathrm{b}}$ & & & & 0.6843 \\
\hline Yes & $11(47.83)$ & $5(45.45)$ & $6(54.55)$ & \\
\hline No & $12(52.17)$ & $7(58.33)$ & $5(41.67)$ & \\
\hline $\mathrm{Ki}-67(\text { mean } \pm \mathrm{SD})^{\mathrm{a}}$ & $25.83 \pm 15.67$ & $21.10 \pm 12.74$ & 0.4543 & \\
\hline
\end{tabular}

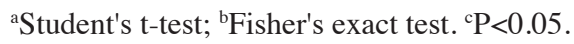

is possible that CSCs are present not only in malignant lesions, but also in benign lesions (15).

In conclusion, immunohistochemical results indicate that all three candidate CSC markers are expressed in ameloblastoma and are possibly involved in cell proliferation, tumor progression and recurrence. Among the CSC marker-positive cells, central stellate reticulum-like cells, situated at the close vicinity of the peripheral ameloblast-like cells, may be candidate cancer stem-like cells in ameloblastoma. Understanding the biological function of the expression of CSC markers in 
ameloblastoma may aid in elucidating their role in tumor pathogenesis, and continued research may lead to the development of more effective therapeutic approaches.

\section{Acknowledgements}

This study was supported by a Grant-in-Aid for Research (C) (no. 21592326) from the Japan Society for the Promotion of Science (JSPS), and a Grant-in-Aid for Young Scientists (B) (nos. 22791977, 20791337 and 22791766) from the Japanese Ministry of Education, Culture, Sports, Science and Technology (MEXT).

\section{References}

1. Gardner DG, Heikinheimo K, Shear M, Philipson HP and Coleman H: Ameloblastomas. In: World Health Organization Classification of Tumours. Pathology and Genetics of Head and Neck Tumours. Barnes L, Eveson JW, Reichart P and Sidransky D (eds.). IARC Press, Lyon pp296-300, 2005.

2. Tumors of odontogenic epithelium. In: Oral and Maxillofacial Pathology. Neville BW, Damm DD, Allen CM and Bouquot JE (eds). Saunders Elsevier, St. Louis, Missouri, pp702-718, 2009.

3. Wu C and Alman BA: Side population cells in human cancers. Cancer Lett 268: 1-9, 2008.

4. Clarke MF, Dick JE, Dirks PB, et al: Cancer stem cells perspectives on current status and future directions: AACR Workshop on Cancer Stem Cells. Cancer Res 66: 9339-9344, 2006.

5. Burkert J, Wright NA and Alison MR: Stem cells and cancer: an intimate relationship. J Pathol 209: 287-297, 2006.

6. Collins AT, Berry PA, Hyde C, Stower MJ and Maitland NJ: Prospective identification of tumorigenic prostate cancer stem cells. Cancer Res 65: 10946-10951, 2005.

7. Olempska M, Eisenach PA, Ammerpohl O, Ungefroren $\mathrm{H}$, Fandrich $\mathrm{F}$ and Kalthoff $\mathrm{H}$ : Detection of tumor stem cell markers in pancreatic carcinoma cell lines. Hepatobiliary Pancreat Dis Int 6: 92-97, 2007.

8. O'Brien CA, Pollett A, Gallinger S and Dick JE: A human colon cancer cell capable of initiating tumour growth in immunodeficient mice. Nature 445: 106-110, 2007.

9. Suetsugu A, Nagaki M, Aoki H, Motohashi T, Kunisada T and Moriwaki H: Chlaracterization of CD133+ hepatocellular carcinoma cells as cancer stem/progenitor cells. Biochem Biophys Res Commun 351: 820-824, 2006.

10. Singh SK, Clarke ID, Terasaki M, et al: Identification of a cancer stem cell in human brain tumors. Cancer Res 63: 5821-5828, 2003.

11. Al-Hajj M, Wicha MS, Benito-Hernandez A, Morrison SJ and Clarke MF: Prospective identification of tumorigenic breast cancer cells. Proc Natl Acad Sci USA 100: 3983-3988, 2003

12. Li C, Heidt DG, Dalerba P, et al: Identification of pancreatic cancer stem cells. Cancer Res 67: 1030-1037, 2007.

13. Prince ME, Sivanandan R, Kaczorowski A, et al: Identification of a subpopulation of cells with cancer stem cell properties in head and neck squamous cell carcinoma. Proc Natl Acad Sci USA 104: 973-978, 2007.
14. Zhou S, Schuetz JD, Bunting KD, et al: The ABC transporter $\mathrm{Bcrp} 1 / \mathrm{ABCG} 2$ is expressed in a wide variety of stem cells and is a molecular determinant of the side-population phenotype. Nat Med 7: 1028-1034, 2001.

15. Xu Q, Yuan X, Tunici P, et al: Isolation of tumour stem-like cells from benign tumours. Br J Cancer 101: 303-311, 2009.

16. Mitsuyasu T, Harada H, Higuchi Y, Kimura K, Nakamura N and Katsuki T: Immunohistochemical demonstration of bcl-2 protein in ameloblastoma. J Oral Pathol Med 26: 345-348, 1997.

17. Zeki SS, Graham TA and Wright NA: Stem cells and their implications for colorectal cancer. Nat Rev Gastroenterol Hepatol 8: 90-100, 2011.

18. Sathi GS, Nagatsuka H, Tamamura R, et al: Stromal cells promote bone invasion by suppressing bone formation in ameloblastoma. Histopathology 53: 458-467, 2008.

19. Sathi GA, Inoue $M$, Harada $\mathrm{H}$, et al: Secreted frizzled related protein (sFRP)-2 inhibits bone formation and promotes cell proliferation in ameloblastoma. Oral Oncol 45: 856-860, 2009.

20. Siriwardena BS, Kudo Y, Ogawa I, Tilakaratne WM and Takata T: Aberrant beta-catenin expression and adenomatous polyposis coli gene mutation in ameloblastoma and odontogenic carcinoma. Oral Oncol 45: 103-108, 2009.

21. Sathi GS, Fujii M, Tamamura R, et al: Juxta-epithelial hyalinization inhibits tumor growth and invasion in ameloblastoma. J Hard Tissue Biol 17: 63-68, 2008.

22. Kumamoto H and Ohki K: Detection of CD133, Bmi-1, and ABCG2 in ameloblastic tumors. J Oral Pathol Med 39: 87-93, 2010.

23. Neuzil J, Stantic M, Zobalova R, et al: Tumour-initiating cells vs. cancer 'stem' cells and CD133: what's in a name? Biochem Biophys Res Commun 355: 855-859, 2007.

24. Huang X, Sheng Y and Guan M: Co-expression of stem cell genes CD133 and CD44 in colorectal cancers with early liver metastasis. Surg Oncol: July 14, 2011 (Epub ahead of print).

25. Steffensen KD, Alvero AB, Yang Y, et al: Prevalence of epithelial ovarian cancer stem cells correlates with recurrence in earlystage ovarian cancer. J Oncol 2011: 620523, 2011.

26. Bleau AM, Huse JT and Holland EC: The ABCG2 resistance network of glioblastoma. Cell Cycle 15: 2936-2944, 2009.

27. Chen Z, Liu F, Ren Q, et al: Suppression of ABCG2 inhibits cancer cell proliferation. Int J Cancer 126: 841-851, 2010.

28. Karhadkar SS, Bova GS, Abdallah N, et al: Hedgehog signalling in prostate regeneration, neoplasia and metastasis. Nature 431: 707-712, 2004.

29. Liao X, Siu MK, Au CW, et al: Aberrant activation of hedgehog signaling pathway in ovarian cancers: effect on prognosis, cell invasion and differentiation. Carcinogenesis 30: 131-140, 2009.

30. Kim JE, Singh RR, Cho-Vega JH, et al: Sonic hedgehog signaling proteins and ATP-binding cassette G2 are aberrantly expressed in diffuse large B-cell lymphoma. Mod Pathol 22: 1312-1320, 2009.

31. Felthaus O, Ettl T, Gosau M, et al: Cancer stem cell-like cells from a single cell of oral squamous carcinoma cell lines. Biochem Biophys Res Commun 407: 28-33, 2011. 